\title{
Zjawiska chemiczno-technologiczne podczas zabiegu cementowania otworu w aspekcie projektowania rur okładzinowych ze szczególnym uwzględnieniem ich wytrzymałości na zgniatanie i rozrywanie
}

\section{Chemical-technological phenomena occurring during borehole cementing operations in terms of casing design, with particular emphasis on their collapse and burst strength}

\author{
Wiesław Witek ${ }^{1}$, Marcin Rzepka² \\ ${ }^{1}$ Firma Konsultingowa „WES” \\ ${ }^{2}$ Instytut Nafty i Gazu - Państwowy Instytut Badawczy
}

\begin{abstract}
STRESZCZENIE: Jedną z najbardziej istotnych kwestii, jaka wymaga rozwiązania w procesie projektowania otworu wiertniczego, jest optymalne zaprojektowanie konstrukcji otworu, w tym odpowiedni dobór poszczególnych kolumn rur okładzinowych oraz ich posadowienie, do zakładanych warunków geologiczno-złożowych oraz warunków cementowania. Dobór poszczególnych kolumn rur okładzinowych do konkretnych warunków geologiczno-technicznych ma szereg nie tylko uwarunkowań, ale również ograniczeń. Głównym naturalnym ograniczeniem jest przyjęta przez API wiele dekad temu swoista unifikacja wymiarowa rur, tzn. typoszereg ze względu na średnicę zewnętrzną rur. Inne elementy tej unifikacji, jak np. typoszereg gatunków stali czy klasycznych połączeń gwintowych i typu PREMIUM, były wdrażane stopniowo w miarę rozwoju technologii wiercenia. Niezależnie od tych uwarunkowań w procesie projektowania rur okładzinowych i doboru rur wydobywczych jedna kwestia zawsze pozostaje niezmienna, czyli zachowanie równowagi między występującymi obciążeniami działającymi na rury w trakcie procesu wiercenia i eksploatacji otworu a graniczną minimalną wytrzymałością mechaniczną rur. W niniejszym artykule dokonano przeglądu metod i wytycznych w zakresie projektowania rur okładzinowych publikowanych przez API oraz programów komputerowych, w tym programu StressCheck, który należy obecnie do powszechnie stosowanych narzędzi w zakresie projektowania rur. Poruszane w artykule zagadnienia wytrzymałościowe odnoszą się głównie do calizny rury, z pominięciem skomplikowanego zagadnienia wytrzymałości samego połączenia gwintowego, w szczególności połączeń typu PREMIUM, którego kwalifikacja nie podlega unifikacji norm API, lecz wytycznym zawartym w normie ISO 13679.
\end{abstract}

Słowa kluczowe: cementowanie rur okładzinowych, rury okładzinowe, wytrzymałość, wytrzymałość na zgniatanie, wytrzymałość na rozrywanie.

\begin{abstract}
One of the most important issues that needs to be addressed in the borehole design process is the optimal design of the borehole structure, including the appropriate selection of individual casing columns and their setting given the assumed geological and cementing-technical conditions. Specific geological and technical conditions imply a number of both conditions and constraints. A kind of dimensional unification of pipes adopted by API many decades ago, i.e. a series according to the outer diameter of the pipes, constitutes the main natural constraint. Other elements of this unification, such as a series of steel grades or of classic and PREMIUM thread connections were implemented gradually as drilling technology developed. Regardless of these conditions, one thing always remains the same when designing casing and selecting production tubing, i.e. maintaining the balance between the existing loads acting on the pipes during the drilling process and operation of the borehole and the minimum mechanical strength of the pipes. This article reviews the methods and guidelines for casing pipe designing published by API and of computer programs, including StressCheck, which is currently one of the commonly used pipe design tools. The strength issues discussed in the article refer mainly to the pipe body, ignoring the complex issue of the strength of the thread connections, especially those of PREMIUM type, whose qualification is not subject to API standards, but to the guidelines contained in ISO 13679.
\end{abstract}

Key words: cementing of casing, casings, strength, collapse strength, burst strength.

\section{Wprowadzenie}

W niniejszym artykule opisane są zagadnienia projektowania rur okładzinowych zgodnie z zasadami, jakie obecnie obowiązują w tym zakresie, przy czym główny nacisk położono na procedury obliczeń wytrzymałościowych rur na zgniatanie i rozrywanie z uwagi na istotę obciążeń, jakie wynikają z zachodzących procesów wiązania zaczynu cementowego,

Autor do korespondencji: M. Rzepka, e-mail: marcin.rzepka@inig.pl

Artykuł nadesłano do Redakcji: 21.10.2020 r. Zatwierdzono do druku: 11.03.2021 r. 
opisanych we wcześniejszej publikacji (Witek i Rzepka, 2021). Ponadto omówiono zagadnienia stosowanych teorii i metod, jak również programów komputerowych opartych w głównej mierze na standardach API, a także na doświadczeniach stanowiskowych dotyczących zwłaszcza oceny zjawiska zgniatania rur o dużych średnicach, czyli wysokim wskaźniku D/t.

Zagadnienia wytrzymałościowe poruszone w niniejszym artykule odnoszą się zasadniczo do wytrzymałości korpusu rury. Zagadnienie wytrzymałości połączeń gwintowych rur okładzinowych jest bardziej skomplikowane i zostało przedstawione wyłącznie informacyjnie.

Z praktycznego punktu widzenia projektowanie rur okładzinowych, a więc wykonanie obliczeń wytrzymałościowych, jest zagadnieniem wiążącym się z dużą odpowiedzialnością z uwagi na charakter prac geologiczno-poszukiwawczych, a więc mających duże znaczenie dla zachowania odpowiedniej ochrony środowiska oraz bezpieczeństwa publicznego. Z tego też wynika powszechne uznanie metod oraz klasyfikacji wykorzystywanych współczynników obliczeniowych, mających globalne znaczenie oraz zastosowanie. Wytyczne w tej kwestii są uznawane jako powszechnie obowiązujące zasady w dziedzinie poszukiwań ropy i gazu zarówno na lądzie, jak i na morzu.

Burzliwy rozwój technologii wierceń, głównie na morzu, w tym wierceń kierunkowych i horyzontalnych, zwanych powszechnie ERD, oraz otworów HP/HT, stanowi poważne wyzwanie dla producentów rur okładzinowych, którzy muszą zapewniać spełnienie wysokich wymagań użytkowo-wytrzymałościowych w stosunku do produkowanych rur. W niniejszym artykule, z uwagi na ograniczoną jego objętość, zagadnienia wytrzymałości rur w procesie projektowania odnoszą się wyłącznie do wybranych kwestii, które wynikają z procesów wiązania zaczynu cementowego, jak i przeprowadzenia samego zabiegu cementowania otworu. Istotne - jak to wskazano $\mathrm{w}$ artykule - w całym procesie projektowania wiercenia otworu jest rozważenie wszystkich scenariuszy obciążeń zarówno w trakcie wytłaczania zaczynu, jak i po jego związaniu.

\section{Ogólne zasady obowiązujące w projektowaniu rur okładzinowych}

Projektowanie rur okładzinowych jest jednym z elementów projektu wiercenia otworu i wynika z szerokiej analizy wielu kwestii technicznych związanych z procesem wiercenia, a przede wszystkim z uwarunkowań geologiczno-złożowych oraz względów bezpieczeństwa wynikających z zapisów HSE stosowanych przez danego operatora.

W poprzednim artykule (Witek i Rzepka, 2021) wskazano na szereg warunków, jakie mają wpływ na proces projektowania poszczególnych kolumn rur okładzinowych, w tym zjawisk zachodzących $\mathrm{w}$ procesie wiązania zaczynu cementowego w operacji cementowania otworu, jak również po okresie zbudowania nowej struktury rura-płaszcz cementowy-skała.

Rozważając podstawowe zasady obowiązujące w projektowaniu rur okładzinowych, należy mieć na uwadze następujące kwestie:

- określenie kryteriów wytrzymałości rur, w tym przyjęcie granicznych kryteriów trwałego uszkodzenia tych rur; - określenie i przyjęcie określonej teorii wytrzymałości dla danej kategorii obciążeń, jakie będą działać na rury w całym okresie żywotności odwiertu;

- określenie obciążeń, jakie będą działać na rury, dla poszczególnych scenariuszy operacyjnych oraz przyjęcie na tej podstawie granicznych obciążeń, jakie będą brane pod uwagę w procesie wyliczania wytrzymałości danej kolumny rur;

- określenie metody wyliczenia wytrzymałości rur okładzinowych dla określonych dopuszczalnych warunków obciążenia;

- określenie warunków środowiskowych mających istotny wpływ na wielkość przyjętych obciążeń projektowych rur (występowanie $\mathrm{H}_{2} \mathrm{~S}, \mathrm{CO}_{2}$ ), w tym odpowiedni dobór gatunku stali tych rur;

- określenie warunków wytrzymałościowych i jakościowych połączeń gwintowych dostosowanych i wynikających z tych kryteriów.

Kryteria powyższe wynikają bezpośrednio z samego projektu wiercenia, który generalnie określa m.in.:

- średnice wiercenia poszczególnych sekcji otworu;

- średnice rur dobrane do średnicy otworu;

- głębokość posadowienia poszczególnych kolumn rur w zależności od wartości określonych gradientów ciśnienia porowego, szczelinowania, jak również dopuszczalnego gradientu wynikającego z granicznej objętości dopływu płynu złożowego w trakcie wystąpienia tzw. kick (erupcji wstępnej), jak również w zależności od warunków geostatycznych otworu.

Zagadnienia te (projektowania wiercenia) nie są przedmiotem rozważań w niniejszym artykule, ponieważ to bardzo obszerne (z uwagi na objętość) kwestie, wykraczające poza tematykę główną, jaką jest złożone zagadnienie projektowania rur okładzinowych.

Rozważając kwestie podstawowych zasad, jakie powinny obowiązywać w projektowaniu poszczególnych kolumn rur okładzinowych lub wydobywczych, należy w pierwszej kolejności wskazać na rozważenie poszczególnych scenariuszy obciążeń, jakie będą działać na daną kolumnę rur okładzinowych lub wydobywczych w trakcie realizacji otworu (procesu wiercenia), jak i po jego wykonaniu w trakcie eksploatacji odwiertu. 
W procesie tym możemy rozważać generalnie dwa scenariusze, a mianowicie:

- scenariusz nr I - który określa dopuszczalne obciążenia przyjęte do obliczeń i działające na daną kolumnę rur okładzinowych $\mathrm{w}$ trakcie zapuszczania rur, a następnie cementowania tych rur i dobicia klocka cementacyjnego celem przeprowadzenia testu ciśnieniowego skuteczności cementowania i potwierdzenia szczelności zapuszczonej kolumny rur;

- scenariusz nr II - który określa dopuszczalne obciążenia przyjęte do obliczeń i działające na daną kolumnę rur okładzinowych po okresie związania zaczynu cementowego i utworzeniu się kamienia cementowego, a które wynikają m.in. ze zjawisk i zachodzących procesów żelowania zaczynu, opisanych w części pierwszej artykułu.

Scenariusz nr I jest z oczywistych względów bardziej istotny z uwagi na fakt, że w trakcie dalszego wiercenia otworu wykonuje się szereg testów ciśnieniowych na rurach, takich jak LoT (ang. leakoff test), czyli test chłonności pod butem rur, lub test IT (ang. integrity test), czyli okresowy test integralności danej kolumny rur, nie mówiąc już o szeregu testów związanych z wgłębnym uzbrojeniem odwiertu i posadowieniem pakerów eksploatacyjnych.

Proces projektowania rur okładzinowych w sensie mechanicznym polega - najogólniej - na zderzeniu i konfrontacji dwóch kwestii, czyli odpowiedniego doboru rur pod względem ich wytrzymałości lub odporności na zniszczenie i przewidywanych obciążeń, jakie będą wynikać z poszczególnych scenariuszy, o których mowa powyżej. Jest to podstawowy i bardzo złożony problem, mający istotny wpływ na integralność zapuszczonej i zacementowanej kolumny rur.

Niezależnie od przyjętej metodologii w procesie projektowania rur - cel każdej z nich jest ten sam, czyli zapewnienie integralności (wytrzymałości) danej kolumny rur dla określonych i przyjętych stanów obciążeń lub kryteriów granicznych obciążeń (zniszczenia).

Każda stosowana metoda obliczeń wytrzymałościowych w każdym procesie projektowania (nie tylko rur) musi zapewniać odpowiedni poziom ufności (bezpieczeństwa), co oznacza, że poziom wytrzymałości wyliczony z zastosowaniem danej metody musi przekraczać poziom wszystkich obciążeń (złożonych), jakie będą działać na daną strukturę - w tym wypadku na rury okładzinowe - $\mathrm{z}$ uwzględnieniem występowania potencjalnych obciążeń wynikających z poszczególnych scenariuszy operacyjnych.

W przemyśle naftowym proces projektowania i selekcji rur okładzinowych napotyka na jedno typowe ograniczenie, jakim jest standaryzacja rur, w tym głównie określenie typoszeregu średnicy zewnętrznej przez Komitet Techniczny API już na początku XX wieku.
Wobec takiej unifikacji początkowo proces projektowania w odniesieniu do rur typoszeregu API był stosunkowo prosty. Po określeniu na podstawie zadanych gradientów ciśnień (porowe, szczelinowania) oraz na podstawie warunków geologicznych i geostatycznych otworu głębokości posadowienia buta rur dla danej kolumny i po dokonaniu analizy obciążeń działających na rury następuje dobór gatunku stali oraz grubości ścianki rury. Cały proces projektowania otworu i poszczególnych kolumn rur zaczyna się od określenia końcowej średnicy otworu (dla końcowej głębokości otworu) i ustalenia w ten sposób średnicy rur. Takie podejście wyznacza sekwencję posadowienia kolejnych kolumn rur (idąc w górę) i ich dobór pod kątem gatunku stali i grubości ścianki. W ten sposób historycznie niejako na początku XX wieku ustalił się typowy schemat zarurowania otworów, idąc od góry:

$$
20^{\prime \prime}-185 / 8^{\prime \prime}-13^{3} / 8^{\prime \prime}-95 / 8^{\prime \prime}-7^{\prime \prime}
$$

Schemat ten utrwalił się w przemyśle naftowym i jest stosowany do tej pory jako najbardziej rozpowszechniony w konstrukcji typowych otworów naftowych i gazowych.

Oczywiste jest, że rozwój wierceń lądowych, a w szczególności wierceń na morzu, w tym wierceń kierunkowych i horyzontalnych, tzw. ERD (ang. extended reach drilling), czyli wierceń o dużym zasięgu, spowodował prawdziwą rewolucję technologiczną w produkcji rur okładzinowych oraz połączeń gwintowych, które są wyłączone z klasyfikacji API i są zwane powszechnie non API connections lub non API grades. Niezależnie od tej rewolucji technologicznej w dziedzinie produkcji rur okładzinowych i wydobywczych podstawowy schemat zarurowania otworów, jaki zaproponowano na początku $\mathrm{XX}$ wieku, pozostaje nadal aktualny i chyba nigdy nie zostanie zmieniony, chociaż w praktyce naftowej stosuje się wiele wręcz niewiarygodnych schematów zarurowania, wykorzystując pośrednie średnice określone w podstawowym standardzie API. Burzliwy rozwój wierceń morskich oraz zastosowanie konstrukcji zarurowania typu liner pozwoliły na zastosowanie różnych schematów, które rozwiązywały szereg problemów technicznych przy osiągnięciu celu złożowo-geologicznego odwiertu, jak również umożliwiły obniżenie kosztów wiercenia.

\section{Główny cel projektowania kolumny rur okładzinowych}

Generalnie proces projektowania danej kolumny rur okładzinowych polega na odpowiednim doborze:

- średnicy rury;

- grubości ścianki rury;

- gatunku stali, z jakiej wykonana jest rura;

- połączenia gwintowego. 
Cały proces można określić jako proces wymuszonej optymalizacji, polegający na określeniu struktury kolumny rur okładzinowych, która ma zdolność do przenoszenia wszystkich obciążeń, jakie będą działać na strukturę w trakcie eksploatacji odwiertu (Firma Konsultingowa „WES”, 2020).

Spośród istotnych czynników ograniczających, a zarazem wymuszonych w procesie projektowania rur okładzinowych można wyróżnić następujące:

- minimalne i akceptowane warunkami współczynniki projektowe dostosowane do przewidywanych obciążeń, jakie będą działać na kolumnę rur w różnych scenariuszach obciążeń; - ograniczenia wynikające ze średnicy pierwszej kolumny rur posadowionych $\mathrm{w}$ więźbie rurowej;

- ograniczenia wynikające z minimalnej wymaganej średnicy wewnętrznej kolumny rur produkcyjnych dla odpowiedniego zaprojektowania wgłębnego uzbrojenia odwiertu i uzyskania optymalnej wydajności odwiertu;

- ograniczenia w zakresie wielkości przestrzeni pierścieniowej dla uzyskania optymalnych warunków cementowania kolejnych kolumn rur okładzinowych.

Rury okładzinowe stanowią fizyczną strukturę, która podlega zmiennym obciążeniom. Struktura ta w połączeniu ze strukturą kamienia cementowego, jaki powstaje w procesie wiązania zaczynu cementowego, staje się kompozytem, który musi przenosić wszelkie obciążenia w sposób bezpieczny, a więc z zachowaniem minimalnych wymogów bezpieczeństwa określonych współczynnikami projektowymi. Wobec tego generalna zasada $\mathrm{w}$ projektowaniu rur okładzinowych musi być wyrażona w następującej formie:

\section{wytrzymałość struktury rura-kamień cementowy > obciążenia działające na rury}

Reguła ta jest zasadna pod warunkiem, że struktura i wytrzymałość kamienia cementowego, czyli innymi słowy jakość cementowania, potwierdzona profilowaniem CBL lub RBT, jest odpowiednia, co oznacza dobre związanie cementu z rurą i ze skałą. Praktycznie zaś zasada ta odnosi się wyłącznie do wytrzymałości struktury rury okładzinowej, ponieważ nie ma możliwości określenia naprężeń w strukturze samego kamienia cementowego, a więc $\mathrm{w}$ procesie projektowania należy zakładać, że całość obciążeń, jakie działają na rury podczas zabiegu cementowania, jak i po związaniu zaczynu, czyli utworzeniu się kamienia cementowego, jest przenoszona wyłącznie przez rury, a nie przez strukturę rura-kamień cementowy-skała. Niestety pojawiają się opinie, wyrażane oficjalnie w różnych ekspertyzach, które kwalifikują kamień cementowy jako czynnik przenoszący ciśnienia hydrostatyczne w przestrzeni pierścieniowej tak jak dla zaczynu, co jest oczywistym błędem. Kwestie te szeroko omówiono w poprzednim artykule (Witek i Rzepka, 2021).

\section{Podstawowe kategorie obciążeń działających na rury okładzinowe}

Wszystkie obciążenia, jakie oddziałują na rury okładzinowe w trakcie wiercenia otworu, a także podczas jego późniejszej eksploatacji, mogą być rozpatrywane w procesie projektowania rur niezależnie, jak również jako kombinacja różnych obciążeń (najczęściej) i przedstawiają się następująco:

a) Obciążenia osiowe (rozciąganie i ściskanie).

Są to obciążenia wywołane podczas:

- zapuszczania rur okładzinowych;

- stawiania na spodzie otworu lub podnoszenia kolumny rur po cementowaniu;

- zmiany temperatury i ciśnienia w otworze.

b) Obciążenia wynikające z oddziaływania ciśnienia.

Są to obciążenia wywołane podczas:

- wystąpienia ciśnienia zgniatania lub rozrywania działającego na rury podczas wstępnej erupcji;

- testów ciśnieniowych;

- opróżniania kolumny rur (częściowego lub całkowitego);

- cementowania;

- szczelinowania;

- zamknięcia wylotu otworu na głowicy;

- innych operacji, które powodują wywołanie stosownych ciśnień.

c) Obciążenia wynikające ze zginania.

Są to obciążenia wywołane podczas:

- wyboczenia kolumny rur;

- zapuszczania rur w otworze kierunkowym lub horyzontalnym;

- zapuszczania rur w otworze pionowym z dużymi zmianami krzywizny, tzw. dogleg.

d) Obciążenia wynikające $\mathrm{z}$ naprężeń ścinających i skręcających.

Są to obciążenia wywołane podczas:

- obracania rurami, np. podczas zapuszczania kolumny typu liner;

- obracania rurami podczas operacji cementowania;

- dopuszczania rur w otworze kierunkowym lub horyzontalnym;

- wiercenia rurami.

Obciążenia wymienione powyżej są przedmiotem omówienia szczegółowego w dalszej części artykułu przy okazji omawiania obliczeń wytrzymałościowych. Niemniej jednak - jak widać z powyższego zestawienia - część z nich ma charakter intencjonalny, czyli przyjęty z założenia z dużym prawdopodobieństwem wystąpienia takich obciążeń, jak np. testy ciśnieniowe czy obciążenia osiowe podczas zapuszczania kolumny rur i cementowania, natomiast część tych obciążeń może mieć charakter przypadkowy (incydentalny), jak np. 
wystąpienie erupcji wstępnej lub wystąpienie nieszczelności, głównie w kolumnie rur wydobywczych.

Wszystkie tego rodzaju obciążenia mogą wystąpić i są możliwe, w związku z czym muszą być one rozpatrywane w procesie projektowania każdej kolumny rur okładzinowych i wydobywczych.

Cały proces projektowania rur okładzinowych i wydobywczych po wstępnej analizie założeń projektowych powinien obejmować następujące etapy:

- identyfikację i określenie wszystkich możliwych scenariuszy obciążenia;

- określenie na podstawie scenariuszy obciążeń parametrów fizycznych tych obciążeń;

- określenie i kalkulację podstawowych obciążeń, jakie będą działać na daną kolumnę rur (w każdym newralgicznym punkcie), a więc określenie wielkości sił osiowych, ciśnień zewnętrznych i wewnętrznych, naprężeń zginających i skrętnych;

- określenie, na podstawie wyznaczonych obciążeń, wytrzymałości rury oraz połączenia gwintowego z zastosowaniem przyjętych powszechnie metod obliczeniowych, np. StressCheck;

- weryfikację wykonanych obliczeń za pomocą innych uznanych metod oraz dokonanie stosownej korekty, idącej w kierunku podniesienia bezpieczeństwa i integralności zapuszczanej kolumny rur.

\section{Zagadnienia teorii wytrzymałości stosowanych w projektowaniu rur okładzinowych z wyszczególnieniem obowiązujących standardów API oraz ISO}

Rury okładzinowe stanowią rodzaj struktury, dla której określenie wytrzymałości jest podstawowym wymogiem w procesie projektowania otworu. Proces ten, mówiąc ogólnie, polega na porównaniu możliwych obciążeń, jakie będą działać na rury $\mathrm{w}$ trakcie wiercenia otworu, jak i jego eksploatacji, do wytrzymałości lub odporności struktury rury dla poszczególnych rodzajów i kombinacji tych obciążeń. Zagadnienia różnych teorii wytrzymałościowych dotyczące projektowania rur okładzinowych mają swoje główne podstawy w teoriach opisanych w prawie Hooka, jak również w pracach na temat teorii sprężystości. Zagadnienia teorii, jak również metodyki stosowanej w projektowaniu rur okładzinowych opisane są w wielu publikacjach (Timoshenko i Goodier, 1970; Bourgoyne et al., 1991; Mitchell et al., 1997; Gabolde i Nguyen, 1999; Kowalewski, 2004; Byrom, 2007; Aadnoy et al., 2009; Witek, 2009a, 2009b; Budak et al., 2010a, 2010b, 2010c).

$\mathrm{W}$ tym zakresie do najbardziej istotnych i obowiązujących należą standardy API opisujące teorie wytrzymałościowe i alternatywne metody ujęte w publikacjach (API BULL 5C3, 1999; ISO/TR 10400:2007).

Poniższy przegląd teorii wytrzymałości dotyczy wyłącznie korpusu rury, natomiast odnośnie do wytrzymałości samego połączenia gwintowego rury sytuacja jest bardziej skomplikowana i wymaga oddzielnego omówienia, i nie będzie przedmiotem rozważań w niniejszym artykule.

Bourgoyne i inni (1991) opisali podstawowe równania wytrzymałościowe zdefiniowane przez Komitet Techniczny API i ujęte w cytowanym powyżej biuletynie API $5 \mathrm{C} 3$ oraz ISO/TR. Generalnie równania te oparte są na podstawowym parametrze wytrzymałościowym, jakim jest wytrzymałość plastyczna, a w zasadzie granica wytrzymałości plastycznej dla danego materiału konstrukcyjnego.

Z uwagi na szeroki zakres materiału poszczególne równania nie są prezentowane w niniejszym artykule, zamieszczony jest jedynie komentarz pod kątem znaczeniowym. Mianowicie poszczególne równania przedstawione w Biuletynie API 5C3 oraz ISO/TR dotyczą następujących przypadków wytrzymałości korpusu rury:

a) wytrzymałość na rozciąganie, tzw. tension - stanowi klasyczna formuła wytrzymałościowa uwzględniająca prosty przypadek rozciągania dla stali z wzięciem pod uwagę wartości granicy plastyczności i wielkości przekroju poprzecznego obliczanego elementu;

b) wytrzymałość na rozrywanie, tzw. burst - stanowi minimalne dopuszczalne wewnętrzne ciśnienie działające na rury określone procedurami API 5C3 lub ISO/TR i porównane do obliczonego ciśnienia różnicowego działającego na korpus rury $\Delta p$. Równanie na określenie dopuszczalnego minimalnego ciśnienia rozrywania jest oparte na teorii wytrzymałości zbiornika ciśnieniowego dla cienkiej ścianki zredukowanej współczynnikiem o wartości 0,875 wyrażającym tolerancję dokładności wykonania rury w procesie walcowania;

c) wytrzymałość na zgniatanie, tzw. collapse - stanowią równania określające wytrzymałość rury na zgniatanie opracowane przez KT API dla czterech reżimów tej wytrzymałości. Przebieg i zakres tych reżimów przedstawiono na rysunku 1.

Jak widać z wykresu, wytrzymałość na zgniatanie dla każdego reżimu jest określona głównie zależnością D/t, czyli średnicy zewnętrznej rury do grubości ścianki rury. Wyliczona minimalna dopuszczalna wartość ciśnienia zgniatania dla danego reżimu jest odnoszona do ekwiwalentnego ciśnienia zgniatania określonego przez producenta rur. Istotne jest, że dla pierwszego, drugiego i trzeciego reżimu oprócz parametru D/t ważna jest także minimalna wartość wytrzymałości plastycznej dla stali, z której wykonane są rury. Te dwa czynniki mają wpływ na wartość obliczonego ciśnienia zgniatania. Zupełnie inaczej 


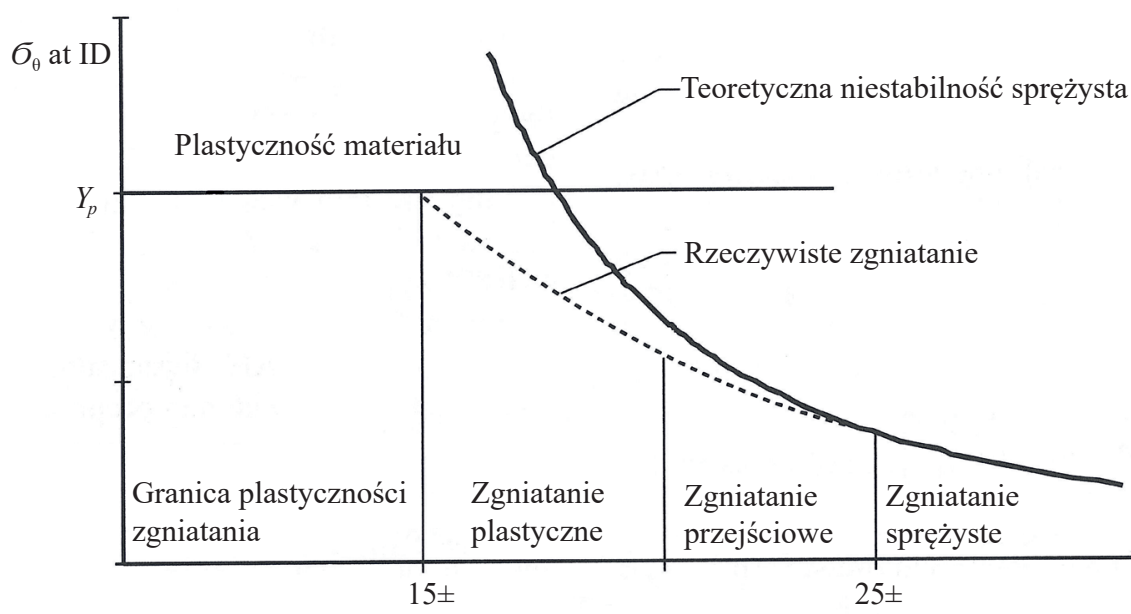

Rys. 1. Wytrzymałość na zgniatanie jako funkcja D/t (według API BULL 5C3, 1999)

Fig. 1. Collapse strength as a function of D/t (API BULL 5C3, 1999)

wygląda kwestia obliczeń dla reżimu czwartego, gdzie decydującym parametrem o wartości dopuszczalnego ciśnienia zgniatania jest wyłącznie parametr D/t, a więc praktycznie wartość granicy plastyczności nie ma tutaj żadnego znaczenia, oczywiście przy zachowaniu minimalnej wartości $\sigma_{y}$ dla danego gatunku stali objętego specyfikacją API. Tak więc nietrudno zauważyć, że np. dla rur 13³\%" o grubości ścianki 10,92 mm wartość ciśnienia zgniatania dla tych rur podawana w katalogach przez wszystkich producentów wynosi 11,5 MPa niezależnie od gatunku stali objętego normami API. Innymi słowy, cytowana powyżej wartość ciśnienia zgniatania 11,5 MPa jest taka sama dla gatunku stali N-80, jak i P-110 lub Q-125. Oznacza to, że w projektowaniu rur na zgniatanie, w szczególności przy założeniu pełnego opróżnienia tych rur, należy przyjmować ekstremalne scenariusze w zakresie obciążeń oraz warunków wykonania rur w procesie produkcji. W procesie projektowania rur należy również pamiętać o tym, że podana w katalogach wartość wytrzymałości na zgniatanie dotyczy warunków wykonania rur określonych w stosownych normach API, w tym API 11960, i innych oraz że jest to wartość odnosząca się wyłącznie do czystego działania ciśnienia różnicowego $\Delta p$ bez uwzględnienia innych obciążeń wynikających z działania sił rozciągających lub ściskania oraz zmian temperatury w otworze. Działanie sił rozciągających podczas występowania obciążenia na zgniatanie rur powoduje zmniejszenie ekwiwalentnej wartości minimalnego ciśnienia podawanej przez producentów. To samo dotyczy przypadku zapuszczania rur w otworze, gdzie temperatura wgłębna przekracza $70^{\circ} \mathrm{C}$, a więc występują warunki geotermalne. W normach API 5C3 i ISO/TR podano wzory do obliczenia dopuszczalnego zredukowanego ciśnienia zgniatania dla tzw. dwuosiowego stanu naprężeń. Natomiast obciążenia ściskające, jakie ewentualnie mogą działać na rury podczas zgniatania, powodują podniesienie wartości dopuszczalnego ciśnienia zgniatania, niemniej jednak praktycznie w kalkulacjach wytrzymałościowych rur na zgniatanie przyjmuje się wartość nominalnie określoną przez producenta rur. Wartość ta jest ograniczona wskaźnikiem projektowym, zwanym inaczej współczynnikiem bezpieczeństwa, który arbitralnie dobierany jest przez projektanta $\mathrm{w}$ ramach powszechnie przyjętych kryteriów, o czym jest jeszcze mowa w dalszej części artykułu.

Trójosiowy stan naprężeń - naprężenia w trójosiowym stanie wynikają z kombinacji jednocześnie występujących obciążeń działających na rury, takich jak: zewnętrzne i wewnętrzne ciśnienie, obciążenia osiowe (rozciąganie) oraz obciążenia wynikające ze zginania (wyboczenie, krzywizna otworu), które wywołują jednocześnie występowanie rozciągania i ściskania w obrębie danego odcinka rury. Teoria występowania trójosiowego stanu naprężeń została pierwotnie opisana w równaniach von Misesa, jak również przez Hencka i polskiego uczonego profesora Politechniki Lwowskiej Hubera. Teoria ta określa tzw. naprężenia ekwiwalentne lub zredukowane (oznaczane w literaturze jako VME, jak również H-M-H), opisywane elipsą w poszczególnych ćwiartkach złożonych obciążeń (Mitchell et al., 1997; Kowalewski, 2004; Byrom, 2007; Aadnoy et al., 2009; Budak et al., 2010a, 2010b, 2010c).

Jak podano na wstępie, metody i teorie obliczeń wytrzymałościowych rur okładzinowych podane w API 5C3 oraz ISO/TR dotyczą wyłącznie korpusu rury, natomiast w odniesieniu do połączeń gwintowych tzw. API, czyli dla gwintów o profilu okrągłym i trapezowym (Buttress i Ex Line), przyjmuje się generalnie zasadę, że wytrzymałość tego rodzaju połączeń wynosi około 95\% wytrzymałości korpusu rury. Inaczej przedstawia się kwestia wytrzymałości połączeń gwintowych tzw. premium, a więc nieobjętych normami API. W tym zakresie obowiązują zupełnie inne zasady kwalifikacji połączeń gwintowych, oparte oczywiście na badaniach w trójosiowym, a więc złożonym stanie naprężeń (ASME, 2005; Alberta Energy Regulator, 2009; Witek, 2009a; API, 2010; Vallourec, 2017; TenarisHydril, 2018; Tenaris, 2020). Procedury tych badań oparte są na bardzo rygorystycznych wymaganiach opisanych w normach API oraz ISO 13679:2017.

\section{Wyznaczanie granicznych obciążeń działających na kolumnę rur okładzinowych dla poszczególnych kategorii i typów tych obciążeń}

W poprzednim rozdziale niniejszego artykułu określono kategorie obciążeń, jakie są możliwe i jakie powinny być 
brane pod uwagę w procesie projektowania rur okładzinowych. Każda kategoria tych obciążeń wynika ze scenariusza tych obciążeń, jakiemu dana kolumna rur jest poddana w procesie wiercenia otworu lub eksploatacji odwiertu. W założeniach projektowych należy zawsze zakładać wystąpienie najbardziej niekorzystnego scenariusza obciążeń.

Przy takim założeniu racjonalności w procesie projektowania rur okładzinowych można uniknąć sytuacji awaryjnych i wyznaczyć wartości obciążeń w sposób bezpieczny.

Dla poszczególnych kategorii obciążeń, zakładając wystąpienie najbardziej niekorzystnego scenariusza, proces ten obejmuje wyznaczenie m.in. dla:

- obciążeń na zgniatanie:

- minimalnego ciśnienia wewnętrznego,

- maksymalnego ciśnienia zewnętrznego;

- obciążeń na rozrywanie:

- maksymalnego ciśnienia wewnętrznego,

- minimalnego ciśnienia zewnętrznego.

Kwalifikując wyznaczenie wartości wyżej wymienionych ciśnień dla tych szczególnych obciążeń, tzn. na zgniatanie i rozrywanie, należy rozważyć, jakie źródła są czynnikiem wywołującym te ciśnienia. Do typowych źródeł ciśnień wywołujących obciążenia zgniatające i rozrywające należą wszelkiego rodzaju płyny, takie jak:

- płyny złożowe, czyli:

- woda złożowa (słodka lub solanka),

- ropa naftowa,

- gaz;

- płyny wiertnicze, czyli:

- płuczka wiertnicza,

- filtrat płuczki wiertniczej;

- niezwiązany zaczyn cementowy, czyli:

- sam zaczyn w formie płynnej;

- filtrat zaczynu cementowego.

- po związaniu zaczynu cementowego, czyli:

- woda złożowa,

- płuczka wiertnicza stosowana podczas cementowania,

- woda zarobowa lub filtrat z zaczynu cementowego.

Wymienione powyżej rodzaje płynów są źródłem wywołanych ciśnień, jakie działają na rury okładzinowe w różnych kombinacjach obciążeń jako scenariusze do obliczeń wytrzymałościowych. Krytyczna wytrzymałość rur okładzinowych odnosi się głównie do dwóch kategorii obciążeń, tzn.:

- obciążeń na zgniatanie;

- obciążeń na rozrywanie.

Nie oznacza to, że wytrzymałość rur i ich połączeń gwintowych na obciążenia osiowe, czyli rozciąganie i ściskanie, jak również obciążenia zginające i ścinające nie jest istotna w kalkulacjach wytrzymałościowych w projektowaniu danej kolumny rur. Szczegółowe omówienie wyżej wymienionych kategorii obciążeń wymaga szerszego wyjaśnienia kilku kontrowersyjnych kwestii, jakie pojawiają się w aspekcie określenia granicznych obciążeń dla tych przypadków. Warto w tym miejscu nadmienić, że obciążenia rur na zgniatanie i rozrywanie wywołane działaniem poszczególnych ciśnień są źródłem powstawania naprężeń złożonych, a więc: naprężeń rozrywających i ściskających, a w skrajnych przypadkach naprężeń zginających i ścinających wynikających z wyboczenia rur (szczególnie rur wydobywczych).

Z tego też względu obciążenia wywołujące zgniatanie i rozrywanie rur okładzinowych wymagają szczególnego omówienia.

\section{Obciązenia rur na zgniatanie, zwane w literaturze angielskiej collapse}

Rozważając wytrzymałość rur na zgniatanie, należy brać pod uwagę najbardziej niekorzystny scenariusz występowania obciążeń, a mianowicie:

- określić minimalne ciśnienie, jakie będzie występować wewnątrz rur;

- określić maksymalne ciśnienie, jakie będzie występować na zewnątrz rur.

Rozważając i kalkulując wartości powyższych ciśnień, zakłada się, że ciśnienia zarówno zewnętrzne, jak i wewnętrzne mają charakter statyczny, czyli gradient ciśnienia płynu, jaki wywołuje dane obciążenia, jest stały.

Ciśnienie wewnętrzne działające na rury jest korzystne z punktu widzenia wytrzymałości rur na zgniatanie, natomiast ciśnienie zewnętrzne daje zupełnie odwrotny efekt. Określenie więc różnicy tych ciśnień będzie rzeczywistą wartością ciśnienia dla wystąpienia zjawiska zgniatania:

$$
P_{w}<P_{z}
$$

gdzie:

$P_{w}$ - oznacza ciśnienie działające wewnątrz rur,

$P_{z}$ - oznacza ciśnienie działające na zewnątrz rur.

W sytuacji odwrotnej, tzn. kiedy:

$$
P_{w}>P_{z}
$$

mamy oczywiście do czynienia z innym scenariuszem obciążeń i występowaniem zjawiska rozrywania rur.

Ciśnienie wewnętrzne w rurach, jakie działa w sytuacjach określania obciążeń rur na zgniatanie, może być wywołane:

- ciśnieniem atmosferycznym (przy pełnym opróżnieniu rur);

- ciśnieniem gazu wypełniającego rury;

- ciśnieniem ropy naftowej wypełniającej rury;

- ciśnieniem wody słodkiej po wymianie płuczki lub po wytłoczeniu zaczynu;

- ciśnieniem solanki sporządzanej na otworze lub płynu stymulacyjnego; 
- ciśnieniem płuczki wiertniczej lub płynu stosowanego w rekonstrukcji odwiertu;

- ciśnieniem wynikającym z kombinacji lub mieszaniny tych płynów.

Najbardziej niekorzystny przypadek obciążenia wewnętrznego rur występuje wówczas, gdy rury są całkowicie opróżnione. Do sytuacji takiej może dojść w trakcie wiercenia poniżej buta rur kolumny wstępnej lub głęboko posadowionej kolumny technicznej na skutek wystąpienia katastrofalnej ucieczki płuczki. Innym przypadkiem może być sytuacja, kiedy ze względów technicznych kolumna rur jest kompletnie opróżniona i wówczas kontrola wartości ciśnienia różnicowego podczas operacji opróżniania jest możliwa, a więc wystąpienie nagłego zgniatania rur jest raczej wykluczone. W przypadkach, kiedy mamy do czynienia z dynamicznym i katastrofalnym zanikiem płuczki i jednoczesnym opróżnieniem kolumny rur, sytuacja staje się o wiele poważniejsza i wystąpienie zjawiska zgniatania jest bardzo prawdopodobne.

Jak widać z powyższego, obliczanie rur na zgniatanie staje się poważnym wyzwaniem w szczególności w sytuacjach operacyjnych trudnych do przewidzenia.

Na poziomie zagłowiczenia otworu (powierzchnia terenu) na ogół przyjmuje się, że obciążenie zewnętrzne działające na rury wynosi zero (z wyjątkiem sytuacji zagłowiczenia otworów morskich). Natomiast poniżej głowicy otworu istnieje szereg możliwości wystąpienia ciśnień zewnętrznych, które mogą być wywołane przez:

- ciśnienie wody słodkiej jako wody zarobowej zaczynu cementowego;

- ciśnienie solanki stosowanej jako woda zarobowa zaczynu cementowego;

- ciśnienie płynu złożowego;

- ciśnienie porowe złoża;

- ciśnienie płuczki stosowanej w trakcie zabiegu cementowania;

- ciśnienie niezwiązanego zaczynu cementowego przed osiągnięciem wartości SGS na poziomie minimum $120 \mathrm{~Pa}$.

Najbardziej niekorzystnym przypadkiem wystąpienia ciśnień zewnętrznych jest przypadek niskiej jakości zabiegu cementowania - wówczas ciśnienie zewnętrzne działające na rury będzie wynikać z gradientu ciśnienia (gęstości) płuczki, jaka była stosowana w trakcie cementowania otworu. Ciśnienie to z reguły jest wyższe od ciśnienia porowego, a niższe od ciśnienia hydrostatycznego wywieranego przez słup zaczynu cementowego z uwzględnieniem oporów hydraulicznych, jakie powstają podczas wytłaczania zaczynu cementacyjnego poza rury.

We wcześniejszej publikacji (Witek i Rzepka, 2021) opisano szczegółowo zjawisko wiązania zaczynu cementowego i tworzenia się struktury żelowej, co ma jednocześnie związek z utratą transmisji ciśnienia hydrostatycznego przez wiążący się zaczyn.
Powstały w wyniku hydratacji zaczynu kamień cementowy traci swoje właściwości transmisji ciśnienia hydrostatycznego, które jest przejmowane przez jeden z wyżej wymienionych płynów, jakie pozostają w przestrzeni pomiędzy rurami a kamieniem cementowym i kamieniem cementowym a skałą.

Z sytuacji takiej, jak to opisano szczegółowo w części pierwszej artykułu, wynika żelazna zasada projektowania rur na zgniatanie, zgodnie z którą związany zaczyn cementowy nigdy nie daje zabezpieczenia przed powstaniem obciążeń zewnętrznych.

Można by takie założenie przyjąć, ale zgodnie z wynikami licznych doświadczeń opisanych w części pierwszej artykułu tego rodzaju założenie jest z gruntu fałszywe. Z tego też względu metodyka i procedury obliczeń wytrzymałościowych rur na zgniatanie powszechnie zakładają, że źródłem ciśnienia zewnętrznego działającego na rury po związaniu zaczynu cementowego i utworzeniu kamienia cementowego jest zawsze płyn (Byrom, 2007; Mitchell et al., 1997; Aadnoy et al., 2009; Alberta Energy Regulator, 2009; Witek, 2009b; API, 2010).

Płynem tym jest z reguły płuczka, jaka była stosowna podczas zabiegu cementowania, i gradient ciśnienia, jaki wynika z gęstości tej płuczki. Bardziej konserwatywne w tym względzie wytyczne (Alberta Energy Regulator, 2009; API, 2010) dopuszczają przyjęcie wody złożowej (solanki) jako medium wywołującego ciśnienie zgniatające po zabiegu cementowania. Gradient takiego ciśnienia ma swoje odniesienie do średniej gęstości solanki na poziomie $1,1-1,2 \mathrm{~g} / \mathrm{cm}^{3}$, a więc poniżej gęstości stosowanego zaczynu cementowego i w większości przypadków poniżej gęstości stosowanej płuczki. Przyjmowanie zaś wody zarobowej o gęstości $1,0 \mathrm{~g} / \mathrm{cm}^{3}$ jako płynu wywołującego ciśnienie zewnętrzne zgniatające działające na rury po związaniu zaczynu i utworzeniu kamienia cementowego jest skrajnie konserwatywne i praktycznie niespotykane w żadnych oficjalnych i zatwierdzonych procedurach dotyczących projektowania rur okładzinowych.

Z powyższej analizy wynika jeden istotny wniosek, mianowicie ze względów bezpieczeństwa z założenia przyjmuje się, że najwyższe ciśnienie zgniatające oddziałujące na rury na zewnątrz po cementowaniu wywierane jest przez płuczkę o gęstości, jaka była stosowana podczas zabiegu cementowania.

Wobec powyższego można podać następujący algorytm obowiązujący jako zasada w określaniu obciążeń rur na zgniatanie: - ciśnienie wewnętrzne - równa się ciśnieniu atmosferycznemu lub wynosi zero;

- ciśnienie zewnętrzne - równa się ciśnieniu hydrostatycznemu słupa płuczki o gęstości, jaka była stosowana podczas zabiegu cementowania.

Zapisany powyżej algorytm jest prosty i stanowi najbardziej bezpieczną zasadę w projektowaniu rur na zgniatanie, która potwierdza się w większości przypadków. 
Przy tego rodzaju założeniach zostanie spełniony warunek zachowania integralności kolumny rur w sytuacjach krytycznych, czyli przy pełnym opróżnieniu rur.

\section{Obciażenia rur na rozrywanie, zwane w literaturze angielskiej burst}

Jak już wskazano powyżej, rozważanie obciążeń rur na rozrywanie jest istotne chociażby $\mathrm{z}$ tego względu, że w porównaniu z obciążeniami na zgniatanie rola działających na rury ciśnień jest odwrotna. Oznacza to, że w przypadku rozrywania rur należy określić maksymalne ciśnienie wewnętrzne i minimalne ciśnienie zewnętrzne działające na rury, a więc zupełnie odwrotnie niż w przypadku zgniatania.

W poprzednim artykule (Witek i Rzepka, 2021) szeroko omówiono kwestię zjawisk zachodzących podczas wiązania zaczynu, a więc transmisji ciśnienia hydrostatycznego. Tak więc w przypadku zgniatania zachodzi również konieczność określenia warunków obciążenia dla najbardziej niekorzystnego scenariusza, czyli przy założeniu maksymalnych ciśnień wewnątrz rur i minimalnych ciśnień działających na zewnątrz rur. W tym momencie dochodzi do pewnego paradoksu w założeniach dotyczących warunków obciążenia rur ciśnieniem zewnętrznym, bo jeżeli przyjmiemy oddziaływanie ciśnienia równe gradientowi płuczki (podobnie jak w przypadku zgniatania), to wówczas dla takiego wariantu obciążeń mamy do czynienia z sytuacją, która jest obciążona dużym ryzykiem. Oczywiście tego rodzaju scenariusz może być zakładany, niemniej jednak jest bardzo ryzykowny i praktycznie nie bierze się go pod uwagę. W związku z tym dla zachowania wysokich wymagań bezpieczeństwa w obliczeniach wytrzymałościowych rur na rozrywanie zakłada się, że czynnikiem wywołującym ciśnienie zewnętrzne działające na rury jest woda zarobowa, która ma w większości przypadków gęstość niższą od gęstości stosowanej podczas cementowania płuczki wiertniczej.

Wykorzystywane pierwotnie w obliczeniach wytrzymałościowych rur okładzinowych metody zakładały generalnie, że obciążenia zewnętrzne pochodzą od gradientów ciśnień wywołanych gęstością wody zarobowej, a nie płuczki, co okazało się $\mathrm{w}$ wielu przypadkach przyczyną awarii w postaci zgniecenia rur lub ich uszkodzenia poprzez rozerwanie - najczęściej na połączeniach gwintowych.

Badanie procesów wiązania zaczynu cementowego i tworzenia się struktury żelowej, i w konsekwencji powstania kamienia cementowego pokazało, że sprawa nie jest do końca jednoznaczna, to znaczy że możemy przyjąć zarówno oddziaływanie ciśnienia płuczki, jak też ciśnienia wody zarobowej lub płynu złożowego.

Problem polega na tym, jakie stosuje się procedury obliczeniowe i jakie stawia się warunki bezpieczeństwa, w szczególności w zakresie ochrony środowiska (nieprzewidziane erupcje gazu lub ropy, głównie na morzu).

Obecnie stosowane procedury $\mathrm{w}$ zakresie projektowania rur oparte są na powszechnie akceptowanym programie StressCheck, który zakłada zawsze najbardziej niekorzystne scenariusze obciążeń. O tym jest jeszcze mowa w dalszej części artykułu.

Z kolei obciążenia ciśnieniem wewnętrznym, jakie działają na rury przy obciążeniu na rozrywanie, związane są z sytuacjami dopływu płynu złożowego (ropy lub gazu), czyli praktycznie $\mathrm{z}$ wywołaniem erupcji wstępnej. W tym przypadku można rozpatrywać szereg scenariuszy obciążeń, które są uzależnione od warunków geologicznych i samej konstrukcji otworu.

Generalnie typowa procedura określania obciążeń wewnętrznych dla przypadku rozrywania rur zakłada, że maksymalne ciśnienie wewnętrzne, jakie będzie oddziaływać, równa się ciśnieniu szczelinowania pod butem rur oraz ciśnieniu gazu w przestrzeni pierścieniowej powyżej buta rur aż do wylotu otworu.

Wobec powyższego można podać kolejny algorytm obowiązujący jako zasada w określaniu obciążeń rur na rozrywanie: - ciśnienie wewnętrzne - równa się ciśnieniu gazu erupcji wstępnej oraz ciśnieniu szczelinowania pod butem rur;

- ciśnienie zewnętrzne - równa się ciśnieniu hydrostatycznemu słupa wody zarobowej o gęstości, jaka była stosowana podczas sporządzania zaczynu cementowego.

Jak już nadmieniono, poszczególni operatorzy mają różne podejście do takiego rozwiązania, niemniej jednak trzeba z całym naciskiem podkreślić, że zapisany powyżej algorytm jest prosty i stanowi najbardziej bezpieczną zasadę w projektowaniu rur na rozrywanie, która potwierdza się w większości przypadków.

\section{Omówienie obecnie stosowanych metod w projektowaniu rur okładzinowych z wyszczególnieniem obowiązujących standardów API oraz ISO}

Jednym $\mathrm{z}$ istotnych założeń $\mathrm{w}$ procesie projektowania rur okładzinowych, oprócz szeregu wyżej omówionych, jest określenie tzw. współczynników projektowania, czyli współczynników bezpieczeństwa. Podstawowym założeniem w procesie projektowania rur okładzinowych jest określenie tzw. projektowych naprężeń roboczych, zwanych dalej PNR, dla danego rodzaju i wielkości obciążeń oraz przyjętych współczynników bezpieczeństwa. Wielkość PNR lub dopuszczalnych obciążeń może być wyrażona na dwa sposoby:

PNR $\leq$ obciążenie projektowane $\div$ współczynnik bezpieczeństwa 
PNR · współczynnik bezpieczeństwa $\leq$ obciążenie projektowane

Obydwa równania są spotykane w metodach projektowania przy założeniu podstawowym, że wartość PNR stanowi zawsze minimalna wytrzymałość materiału rury, a więc najczęściej granica plastyczności. Przekroczenie wartości PNR wiąże się z wystąpieniem obciążeń granicznych w zakresie poza sprężystością materiału, co może zakończyć się awarią lub nawet katastrofalnym zniszczeniem rury.

Głównym celem stosowania współczynników bezpieczeństwa w projektowaniu rur okładzinowych i wydobywczych jest wyeliminowanie sytuacji awaryjnych ze względu na:

- względną ocenę wytrzymałości rur;

- względne określenie występujących obciążeń;

- niepewność związaną z charakterem prac wiertniczych, w tym głównie poszukiwawczych za ropą i gazem.

Typowe współczynniki bezpieczeństwa stosowane w obliczeniach wytrzymałościowych w odniesieniu do korpusu rury zestawiono w tabeli 1.

Tabela 1. Typowe współczynniki bezpieczeństwa

Table 1. Typical safety factors

\begin{tabular}{|l|c|}
\hline \multicolumn{1}{|c|}{ Rodzaj obciążeń } & Korpus rury \\
\hline \hline Trójosiowy stan naprężeń - VME & 1,25 \\
\hline Obciążenia osiowe & $1,3-1,6$ \\
\hline Rozrywanie & $1,0-1,25$ \\
\hline Zgniatanie & $1,0-1,15$ \\
\hline
\end{tabular}

Zestawione w tabeli 1 współczynniki są wartościami empirycznymi opartymi na bogatym doświadczeniu i tradycji światowego przemysłu naftowego. Niektóre firmy stosują własne współczynniki bezpieczeństwa w projektowaniu rur, co może wynikać z unikalnych doświadczeń związanych z danym złożem lub regionem poszukiwań ropy i gazu oraz z innej kombinacji obciążeń działających na rury, a ponadto z okresu eksploatacji danego odwiertu.

Wielkości stosowanych współczynników bezpieczeństwa są uzależnione również od uwarunkowań środowiskowych, nie mówiąc już o zawartości gazów kwaśnych, ale z pewnością wartości te mogą być inne dla wierceń morskich niż wierceń lądowych i są bardziej rygorystyczne w odniesieniu do otworów poziomych lub ERD, jak również otworów HT/HP (otwory o wysokiej temperaturze i wysokich gradientach ciśnienia), czyli otworów ultragłębokich i geotermalnych.

Obecnie w projektowaniu rur okładzinowych i wydobywczych, obok ciągle obowiązujących zasad i metod wynikających z rekomendacji standardów API BULL 5C3 oraz ISO/TR, stosuje się program komputerowy StressCheck opracowany przez firmę Landmark-Halliburton. Program ten jest powszechnie używany na świecie przez wszystkich głównych operatorów światowych, tzw. Big Sisters, jak również głównych operatorów krajowych, czyli PGNiG SA oraz ORLEN Upstream Sp. z o.o. Program StressCheck został opracowany na podstawie zbioru przeanalizowanych danych około 60000 przypadków różnorodnej konstrukcji otworów, jak i warunków geologiczno-technicznych spotykanych w głównych rejonach poszukiwań ropy i gazu zarówno na lądzie, jak i na morzu. Uniwersalność programu StressCheck do projektowania rur okładzinowych i wydobywczych polega m.in. na tym, że:

- obejmuje swoim zakresem komplet różnorodnych obciążeń działających na rury w trakcie wiercenia i eksploatacji otworu;

- obejmuje swoim zakresem różnorodne scenariusze tych obciążeń wynikające z sytuacji otworowych;

- obejmuje swoim zakresem cały katalog stosowanych połączeń gwintowych zarówno API, jak i połączeń typu premium;

- ustala realne współczynniki bezpieczeństwa w obliczeniach wytrzymałości rur potwierdzone praktycznie, co świadczy o dużej wiarygodności i powszechności stosowania tego programu;

- wypracowany finalnie algorytm programu jest łatwy w obsłudze i pozwala na wprowadzanie różnorodnych symulacji zarówno obciążeń, jak i warunków otworowych w celu uzyskania optymalnej konstrukcji otworu oraz poszczególnych kolumn rur.

Jak już wspomniano powyżej, program StressCheck jest obecnie podstawowym narzędziem w projektowaniu rur okładzinowych i wydobywczych w przemyśle naftowym, a jego podstawowe założenia stanowią część wytycznych w zakresie obliczeń wytrzymałościowych stosowanych obligatoryjnie przez poszczególnych operatorów, w tym PGNiG SA oraz ORLEN Upstream Sp. z o.o.

Przykładem takiej kompilacji założeń projektowych jest zestaw danych i wytycznych obliczeń wytrzymałościowych dla prowadnikowej kolumny rur okładzinowych (np. głęboko posadowionych rur $133 / 8$ " - tabela 2). Tego rodzaju założenia są powszechnie stosowane w światowym przemyśle naftowym, w tym w Polsce (Witek, 2009b; Halliburton, 2020).

\section{Podsumowanie}

Prezentowany artykuł stanowi omówienie jedynie części zagadnień projektowania rur okładzinowych i wydobywczych z uwzględnieniem głównie podstawowych kwestii wytrzymałościowych w zakresie zgniatania i rozrywania rur w sytuacjach, które są często niedoszacowane. 


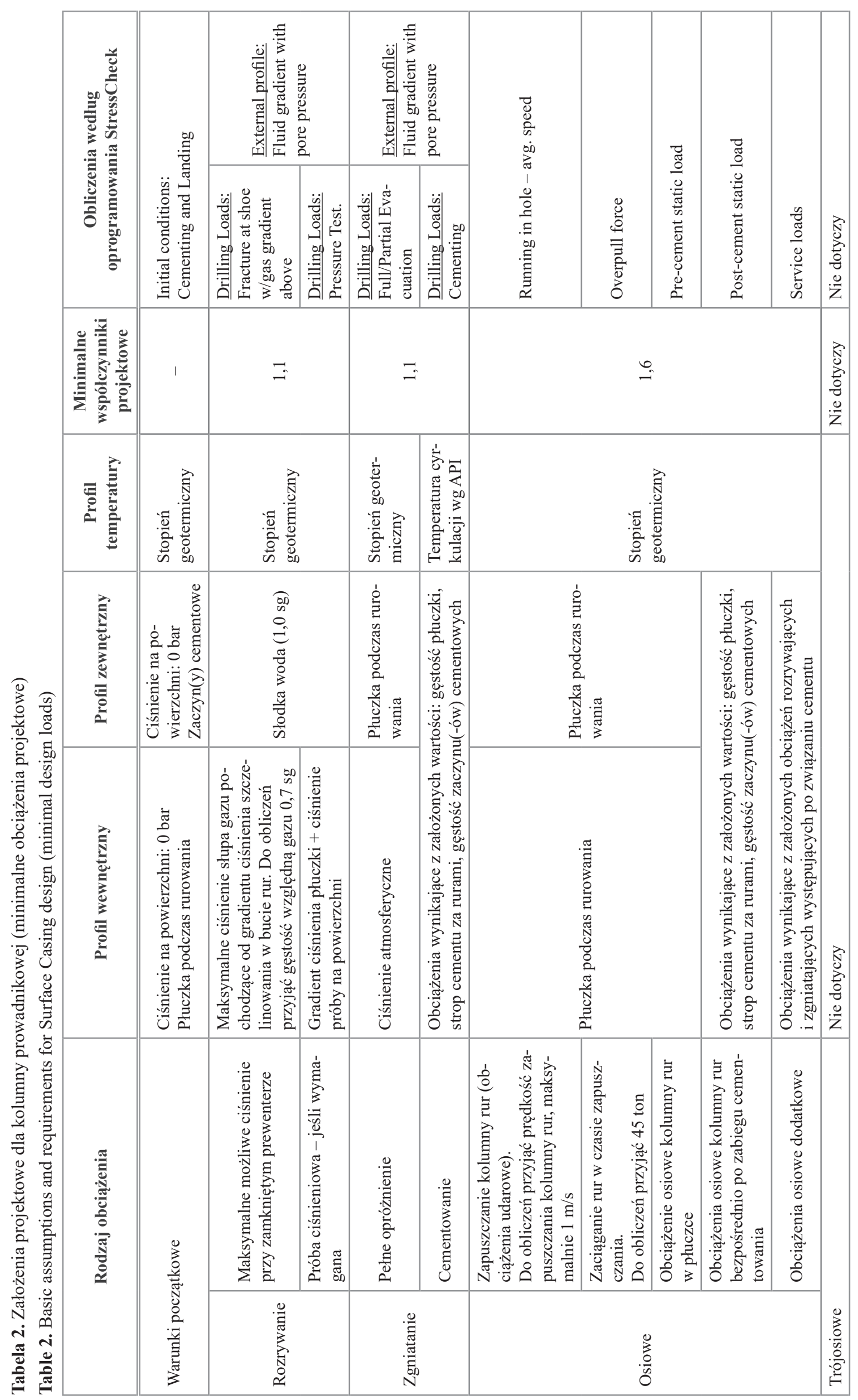


Wydawać by się mogło, że obliczenia wytrzymałościowe rur zapuszczanych do stosunkowo płytkich otworów (do $2000 \mathrm{~m}$ ) nie stanowią praktycznie żadnego problemu, ale brak dobrego rozeznania w zakresie rozkładu ciśnień po zabiegu cementowania i utworzeniu się kamienia cementowego może stanowić poważny problem przy doborze rur, związany z niedoszacowaniem ciśnień (Witek i Rzepka, 2021).

Znajomość procesów chemicznych, jakie zachodzą w trakcie sporządzania zaczynu cementowego, a następnie podczas jego wytłaczania oraz tworzenia się struktury żelowej, już na etapie projektowania rur pozwala na uwzględnienie najbardziej niekorzystnego scenariusza obciążeń, jakie będą działać na rury podczas różnego rodzaju operacji technologicznych w trakcie wiercenia otworu oraz w czasie jego eksploatacji. To stanowi główny cel niniejszej prezentacji.

Opisane zjawiska w zakresie technologii cementowania są powszechnie znane $\mathrm{z}$ bogatej literatury i dobrze $\mathrm{w}$ artykule udokumentowane, niemniej jednak praktyczne wykorzystanie tej wiedzy okazuje się często znikome lub jest po prostu przez niektórych projektantów otworów ignorowane w procesie doboru rur okładzinowych.

Wobec powyższego bardzo ważnymi wnioskami, jakie mogą wypływać z treści niniejszego artykułu, są następujące stwierdzenia:

a) $\mathrm{W}$ procesie projektowania rur okładzinowych i wydobywczych należy zawsze rozważać występowanie najbardziej niekorzystnych scenariuszy obciążeń, jakie mogą działać na rury - zarówno w trakcie samego zabiegu cementowego, jak i po związaniu zaczynu, czyli utworzeniu się kamienia cementowego.

b) Najlepszym zalecanym aktualnie narzędziem stosowanym w przemyśle naftowym do projektowania rur okładzinowych i wydobywczych jest program StressCheck, który gwarantuje wysoki stopień bezpieczeństwa w zakresie integralności zapuszczanych kolumn rur.

c) Zabieg cementowania każdej kolumny rur zapuszczanej do otworu jest jednym z najważniejszych elementów w procesie projektowania otworu $z$ uwagi na jego nieodwracalność, ponieważ jest ostatnią lub prawie ostatnią czynnością po zapuszczeniu rur $\mathrm{w}$ złożonym procesie realizacji otworu.

Artykuł powstał na podstawie pracy statutowej pt. Zaczyny cementowe o krótkich czasach żelowania $i$ wiazania do uszczelniania plytkich otworów wiertniczych - praca INiG - PIB na zlecenie MNiSW; nr zlecenia: 0017/KW/2018, nr archiwalny: DK-41000017/2018 oraz doświadczeń i prac prowadzonych w ostatnich latach przez Firmę Konsultingową „WES”.

\section{Literatura}

Aadnoy B., Cooper I., Miska S., Mitchell R.F., Payne M.L., 2009. Advanced Drilling and Well Technology. Society of Petroleum Engineers: 17-84. ISBN: 978-1-55563-145-1.

Alberta Energy Regulator (Canada), 2009. Directive 010: Minimum Casing Design Requirements Dec 222009 Eff. June 2013.<https:// www.aer.ca/regulating-development/rules-and-directives/directives/directive-010> (dostęp: 09.10.2020).

API, 2010. Isolating Potential Flow Zones During Well Construction, API STANDARD 65 - Part 2. December. <https://www.api.org/ /media/ Files/Policy/Exploration/Stnd_65_2_e2.pdf> (dostęp: 09.10.2020).

API BULL 5C3, 1999. Bulletin on Formulas and Calculations for Casing, Tubing, Drill Pipe, and Line Pipe Properties. $<$ https://global.ihs.com/doc_detail.cfm?document_name=API\%20BULL $\% 20$ 5C3\&item_s key $=00010624>$, API, Washington DC.

ASME, 2005. ASME Presentation. Advances in Casing Design with ISO DIS 10400. <http://www.docdatabase.net/more-advancesin-casing-design-with-iso-dis-10400-1019765.html> (dostęp: 09.10.2020).

Bourgoyne A.T., Millheim K.K., Chenevert M.E., Young F.S. Jr., 1991. Applied Drilling Engineering. SPE Textbook Series vol. 2. ISBN: 978-1-55563-001-0.

Budak P., Szpunar T., Witek W., 2010a. Kryteria doboru rur okładzinowych i wydobywczych jako funkcje wytrzymałości i wytężenia materiału oraz rodzaju i typu połączenia gwintowego. Wiadomości Naftowe i Gazownicze, 4: 4-10.

Budak P., Szpunar T., Witek W., 2010b. Kryteria doboru rur okładzinowych i wydobywczych jako funkcje wytrzymałości i wytężenia materiału oraz rodzaju i typu połączenia gwintowego: RURY HC „High Collapse”. Wiadomości Naftowe i Gazownicze, 5: 4-7.

Budak P., Szpunar T., Witek W., 2010c. Zagadnienia wytrzymałości i wytężenia materiału przy projektowaniu kolumny rur okładzinowych w odniesieniu do zjawisk zachowania się górotworu w trakcie wiercenia i po odwierceniu otworu. Wiadomości Naftowe i Gazownicze, 3: 4-8.

Byrom T.G., 2007. Casing and liners for drilling and completion. Gulf Publishing Company.

Firma Konsultingowa „WES”, 2020. <http://fk-wes.pl> (dostęp: 09.10.2020).

Gabolde G., Nguyen J.P., 1999. Drilling Data Handbook. Seventh Edition. Instytut Francais du Petrole Publications. ISBN-13: 978-2710807568. ISBN-10: 2710807564.

Halliburton, 2020. Casing Equipment. <https://www.halliburton.com/ en-US/ps/cementing/casing-equipment/default.html> (dostęp: 09.10.2020).

ISO/TR 10400:2007. Petroleum and natural gas industries - Equations and calculations for the properties of casing, tubing, drill pipe and line pipe used as casing or tubing. <https://www.iso.org/ standard/44107.html> (dostęp: 09.10.2020).

Kowalewski Z.L., 2004. Podstawy wytrzymałości materiałów. Oficyna Wydawnictwa Politechniki Warszawskiej, Warszawa.

Mitchell R.F., Miska S., Wagner R.R., 1997. Casing and Tubing Design. [W:] Economides M.J., Watters L.T., Norman S.D., Petroleum Well Construction. John Wiley \& Sons Duncan, Oklahoma. <https://www.scribd.com/document/49893936/ Economides-M-J-Watters-L-T-and-Norman-S-D-PetroleumWell-Construction> (dostęp: 09.10.2020).

Tenaris, 2020. TenarisHydril running manual. $<$ https://www.tenaris. $\mathrm{com} / \mathrm{en} /$ products-and-services/octg/tenarishydril-running-manual/> (dostęp: 09.10.2020). 
TenarisHydril, 2018. Premium Connections Cataloque. $<$ https://www. tenaris.com/media/1wvb3eti/tenarishydril-premium-connectionscatalog.pdf> (dostęp: 09.10.2020).

Timoshenko S.P., Goodier J.N., 1970. Theory of Elasticity (third edition). McGraw: New York.

Vallourec, 2017. VAM BOOK - Technical Manual, November. <http:// www.vamservices.com/Library/files/VAM\%C2\%AE\%20Book. pdf> (dostęp: 09.10.2020).

Witek W., 2009a. Dobór rur okładzinowych oraz połączeń gwintowych dla obszaru poszukiwań Przedgórza Karpat oraz Nasunięcia Karpackiego. Opracowania dla PGNiG S.A. Oddział w Sanoku. Firma Konsultingowa ,, WES”.

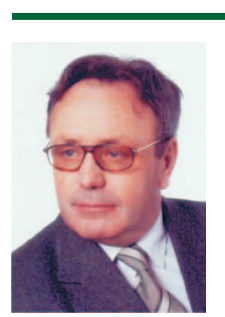

Dr inż. Wiesław WITEK

Dyrektor Firmy Konsultingowej WES

ul. Warszawska 17

05-504 Złotokłos

e-mail:wwitek@fk-wes.pl
Witek W., 2009b. Opinie oraz ekspertyzy. Materiały archiwalne niepublikowane. Firma Konsultingowa ,, WES”.

Witek W., Rzepka M., 2021. Zjawiska chemiczno-technologiczne podczas zabiegu cementowaniaotworu w aspekcie projektowania rur okładzinowych. Nafta-Gaz, 2: 92-105, DOI: 10.18668/ NG.2021.02.04.

\section{Akty prawne i dokumenty normatywne}

ISO 13679:2019 Petroleum and natural gas industries — Procedures for testing casing and tubing connections.

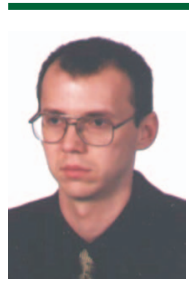

Dr inż. Marcin RZEPKA

Kierownik Laboratorium Zaczynów Uszczelniających w Zakładzie Technologii Wiercenia

Instytut Nafty i Gazu - Państwowy Instytut Badawczy ul. Lubicz $25 \mathrm{~A}$

31-503 Kraków

E-mail: marcin.rzepka@inig.pl

OFERTA BADAWCZA ZAKKADU MIKROBIOLOGII

- badania procesów mikrobiologicznych w środowisku ztożowym podziemnych magazynów gazu ziemnego (PMG);

- dziatania prewencyjne - zastosowanie biocydów, środków typu neutralizatory $\mathrm{H}_{2} \mathrm{~S}$ oraz inhibitorów bakterii redukujących siarczany (SRB), generowanie biogennego $\mathrm{H}_{2}$;

- bioremediacja gruntów skażonych związkami ropopochodnymi;

- biodegradacja związków polimerowych wchodzących w sktad ptynów wiertniczych;

- mikrobiologiczne technologie stymulacii eksploatacij ztóż węglowodorów;

- mikrobiologiczne metody poszukiwawcze: metodą powierzchniową oraz mikrobiologicznego profilowania odwiertów;

- badania testowe preparatów antybakteryjnych (biocydów);

- badania bakteriologiczne wody pitnej;

- analizy mikrobiologiczne wód termalnych.

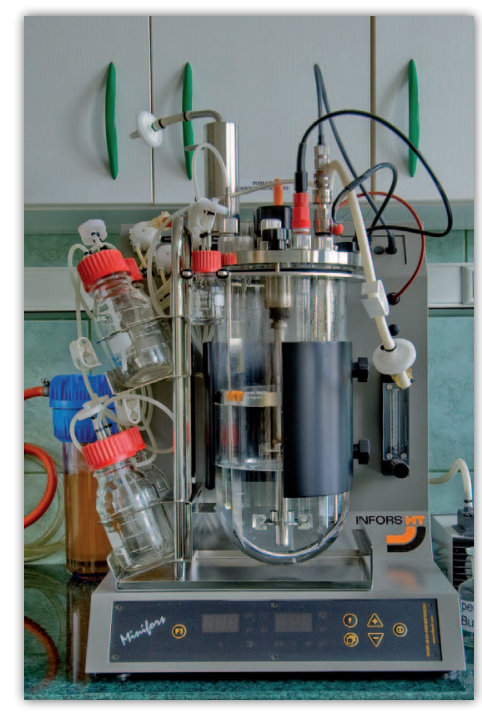

Kierownik: dr Piotr Kapusta Adres: ul. Lubicz 25 A, 31-503 Kraków Telefon: 126177690 Faks: 124303885 E-mail: piotr.kapusta@inig.pl 